anthropology \& materialism

\section{Anthropology \& Materialism}

A Journal of Social Research

3 | 2016

Utopia: The Elsewhere and The Otherwise

\title{
Utopian Pulse - Flares in the Darkroom
}

An interview with Oliver Ressler

\section{Oliver Ressler and Meike Schmidt-Gleim}

\section{(2) OpenEdition \\ Journals}

Electronic version

URL: http://journals.openedition.org/am/592

DOI: $10.4000 / a m .592$

ISSN: 2364-0480

Publisher:

CETCOPRA, CRASSH - Center for Research in the Arts Social Sciences and Humanities, Fakultät Gestaltung - Universität der Künste Berlin

Electronic reference

Oliver Ressler and Meike Schmidt-Gleim, « Utopian Pulse - Flares in the Darkroom », Anthropology \&

Materialism [Online], 3 | 2016, Online since 01 December 2016, connection on 19 April 2019. URL :

http://journals.openedition.org/am/592 ; DOI : 10.4000/am.592

This text was automatically generated on 19 April 2019.

Tous droits réservés 


\title{
Utopian Pulse - Flares in the Darkroom
}

\author{
An interview with Oliver Ressler \\ Oliver Ressler and Meike Schmidt-Gleim
}

\section{EDITOR'S NOTE}

The volume Utopian Pulse - Flares in the Darkroom edited by the artists Ines Doujak and Oliver Ressler ${ }^{1}$ is a programmatic reader on concrete utopian projects. It gives new life to the old concept of utopia by positioning utopian projects in the here and now, without succumbing to a phantasmagorical image of the present time. Utopia is conceived as a dialectics between "...a negation of what is and a necessarily imperfect assertion of that which is not (yet)" and as such a continuous and on-going struggle for a different world. The book assembles the positions and experiences of seven "salons" initiated by Ressler and Doujak and put up by different artist-curators. The salons were first shown at the Secession in Vienna in 2014, followed by an exhibition at Württembergischer Kunstverein Stuttgart in 2015. The salons reported and displayed concrete utopian activities or interventions such as anti-gentrification projects, Fluchthilfe (escape aid), workercontrolled companies, etc. These presentations are framed by theoretical contributions on the concept of utopia.

An Interview with one of the editors and founders of the project, Oliver Ressler, depicts the incentive to pick up the old concept of utopia and give it a new direction. Oliver Ressler has been engaged in political art for 20 years. His critical and investigative films and installations on issues of economics, democracy, global warming, forms of resistance and social alternatives have been presented worldwide. A retrospective of his work has been shown at Centro Andaluz de Arte Contemporaneo - CAAC in Seville until January 10, 2016. Unfortunately the co-editor and co-founder of the project Utopian Pulse Ines Doujak could not participate in the interview, but her experience with political and in particular queer-feminist and anti-racist art projects fueled the Utopian Pulse project. 
1 Meike Schmidt-Gleim: Throughout the book Utopian Pulse - Flares in the Darkroom I found many different ways and concepts to describe the Utopian Pulse: "public happiness", "an act within the given that imagines, foreshadows...a life incommensurable with THINGS AS THEY ARE", "latency (Bloch)", "negation (Adorno)", "a specific situation lived in certain space temporalities...", "utopia is necessarily imperfect assertion of which is not yet...", "imagination/hope/desires", "not an island... (isola is not an island)", "concrete utopia". Can you point out what the various descriptions in the Utopian Pulse have in common? What is utopia for you?

2 Oliver Ressler: For me utopia is not an imagination of a different, better world. I believe we should rather imagine utopia as something that exists already in the here and now. Glimpses of utopia appear in certain moments in political activities and movements and open up directions to be explored or pursued. Eduardo Galeano described utopia like this: "When I walk two steps, it takes two steps back. I walk ten steps and it is ten steps further away. What is utopia for? It is for this, for walking." According to this, utopia might be imagined not as a place in which you arrive but the journey toward it. Such an openended approach that avoids predefined patterns I also see in the Zapatist concept of "asking we walk".

3 The exhibition project and book Utopian Pulse - Flares in the Darkroom assemble ideas, concepts, ways of living that the involved artists, theorists and writers believe are worthwhile. The entire endeavour I carried out in collaboration with the artist Ines Doujak, who has different interests and a different approach of how to work, which helped developing a much wider angle than it would have become otherwise.

4 MSG: Could you elaborate on the reference to walking in the context of other theories and practices of walking, e.g. "la théorie de la dérive" of the Situationists, the figure of the flâneur of Walter Benjamin or Michel de Certeau's everyday practice, of walking in the city body itself? Is walking a metaphor or a physical practice?

OR: The concept of "walking” hasn't been so central for Utopian Pulse - Flares in the Darkroom, even though Galeano's metaphor popped up in different exhibitions and texts. For me personally the Zapatist concept of "asking we walk" has been a really central paradigm of how to imagine achieving change. Not to have this fully elaborated concept, which you struggle to introduce through whatever means necessary, but to listen to the people, to their wishes and expectations, to introduce a couple of measures, to see how they effect peoples lives, to listen carefully to what people think about them, with the possibility to revoke the measures or to expand them depending on what appears favourable. Through such a procedure of involving people change becomes a democratic process. Democracy is not an end you want to achieve, but an integral part of the social process, which of course makes it impossible to predefine a path. Such an open approach of governing in obedience to those below seems also a good approach in relation to our contemporary knowledge of the authoritarian outcome of several utopias or revolutionary movements in the twentieth century, which in the majority attempted to follow a well-defined recipe.

6 MSG: To what extent is your definition new or a redefinition of traditional concepts of utopia? 

utopia as a far distant, isolated island. In Utopian Pulse - Flares in the Darkroom Ines Doujak and I took inspiration from the theorist Matthew Hyland. He imagines utopia not as 'an imaginary world', but a work or act within the given world that imagines, foreshadows, calls forth or negatively invokes a life incommensurable with Things As They Are. Hyland elaborates these ideas in a central essay that we commissioned for the publication.

MSG: As you mentioned, defining an ideal society often led to an authoritarian outcome. Why do you think, then, that it is nevertheless interesting to pick up this concept again? Is part of your position polemic and if so, who is your opponent or adversary?

OR: In the course of the financial and economic crisis the capitalist system has unmasked itself for the majority of the people. It dominates no longer because people agree with it but because people still believe there is no alternative. The capitalist system seems to be so firmly in control that it does not even need people believing in it any longer. It functions with an absence of imagination. In such a moment it appears crucial to establish platforms for imagination, and I think for many people who participated in the events and spent time in the exhibition-cycle, Utopian Pulse - Flares in the Darkroom was successful in this.

10 My interest in the concept of utopia regards how fruitful it is to use the term nowadays. Even though the notion "utopia" is only seldom used in current political debates, you can feel it is there, somewhere hidden in the background. For example I tend to interpret the central demand of the 15M movement in Spain for a "Real democracy now!" as a demand for utopia to become real. It is the demand for a better world to become real now. Without hope of alternative futures, we can only look backwards nostalgically, if depending from the position we look - there is anything positive to look backwards at all. Therefore, politically we need utopia. Utopian thinking and imagination seem to be prerequisites for initiating discussions, about how to organise society - in a more egalitarian, less hierarchical manner. Utopian thinking can address and formulate wishes, which is a good starting point to build something new.

MSG: Can you give some examples, describe projects of groups that appear in the book who best fulfil what you are looking for in your project Utopian Pulse - Flares in the Darkroom?

OR: For Utopian Pulse - Flares in the Darkroom Ines and I established a network of seven artists who do curatorial work as part of their artistic practice, even though some of them do not use the term "curators" for their work. These artist-curators put together one exhibition each in the gallery of the Secession in Vienna in 2014 dealing with what they consider important aspects or themes in relation to utopia. Already this structure points out that I imagine work on utopia a collaborative process rather than the imaginative work of an individual. What these seven exhibitions have in common is that the artworks are situated in the existing world and position themselves against the deadening political and social reality. They make visible utopian flares in the here and now. For example Salon Fluchthilfe by Australian artist Zanny Begg brings together international artists focusing on undocumented migration with local artists and activist groups. She transforms the exhibition into a space in which rather than the usual discussions what took place was work assemblies of a self-organised refugee group in Vienna and its supporters. To 
establish new alliances and to use the gallery for political activities are important elements we tried to achieve within the project.

MSG: In Antke Engel's texts the salon presentations are compared to a Variety Show. Do you feel this label pins down well the project? Her description is quite astonishing as it brings politically motivated projects close to shallow entertainment.

OR: There are salons within Utopian Pulse - Flares in the Darkroom that relate to variety shows. Salon Klimbim, a one-day event, which was the first public appearance of Utopian Pulse in January 2014, combined different formats such as short talks, screenings and artistic performances with music, dancing and a bar. The choreography of the evening allowed the simultaneity of different events, their overlapping, which created a strong moment for its hundreds participants. There are also two salon presentations where links to variety shows could be drawn: Cuartos de utopia by Pedro G. Romero/Máquina P.H. combined flamenco with research into the so-called Gypsy Urbanism and consisted of 13 (!) performative events that took place within one week in the framework of this exhibition. Salón de Belleza (Beauty Salon) by Miguel A. López merges artworks that explore techniques of body intervention with colonial history, indigenous politics and queerness, whereas some of the performances employed popular formats, which you could relate to variety shows.

MSG: So why is the format of the variety show interesting in the context of utopian projects? Is it maybe, because a variety show is precisely not Hochkultur (high culture), but an element of popular culture?

OR: If we look at contemporary artistic production I would argue the distinction between high and low culture has already been dissolved to a large extent. I would describe the inclusion of every imaginable field of popular culture already as a mainstream strategy in the art world, so for my part I do not see a lot of meaning involving myself too much in the dissolution of boundaries which are already very permeable.

MSG: I liked very much how the Utopian Pulse emphasises energy, passion and emotion [sister in tears, fun, anger (Alice Creischer)], and throughout the book you can indeed feel energy and emotional involvement. How far are these rather irrational forces important for the realisation of concrete Utopia?

OR: The idea behind Salon Klimbim that was conceived by Ines Doujak and Fahim Amir in collaboration with me was so as to create an event where art and entertainment can happen without hierarchies, and to create an energetic and intense event that allows putting forth the feeling of how utopia could feel like. As all of the artist-curators participated in Salon Klimbim, maybe its energy also inspired some of them when they conceptualised their salons later. I think any utopian project needs to establish space for people's involvement, for their wishes and desires. And as emotions - anger, love or empathy - are central driving forces that make people become active they should not be excluded from a political project. Any utopian project, which is too narrow and predefined, is endangered to fail. People who participate in social movements, in demonstrations, occupations or blockades also often experience their collective power as something joyful and highly emotional. There are not many fields in our rationally organised capitalist societies where something such as for example mutual aid can be experienced, where people who sometimes meet for the first time care for each other. A 
demonstration or occupation can also be a site where people come together and celebrate!

MSG: Capitalism as adversary of utopia appears as a red thread through the book. Why capitalism (and not racism, sexism etc.)?

OR: Of course I also see racism and sexism or homophobia or nationalism as adversary to utopia. Along with theorists such as Étienne Balibar I see that capitalism needs ideologies of inequality (like racism and sexism and others), in order to makes legitimate the existing relations of inequality in capitalism. Racism and sexism are not central in our society by coincidence, but have a function for capitalism's reproduction. Therefore I assume your observation is probably right in that in several essays and projects capitalism serves as an adversary of utopia.

\section{MSG: So capitalism is the central contradiction ("Hauptwiderspruch")?}

OR: Progressive social movements show that it is possible to have an overall aim such as to overthrow the current capitalist system and to establish a more egalitarian system, and already in the struggle taking care that decisions are being made by women and men equally, that people of colour or minorities are represented and have visibility when interacting with media for example. This categorisation in a "central contradiction" and "side contradictions" are categories from Marxist debates that to me appear a bit outdated today. There is no way for women and people of colour to involve in a struggle that doesn't take their interests seriously from the first day on.

MSG: The actors of Utopian Pulse, or the concrete utopias seem to be those who are marginalised by capitalism: refugees, immigrants, women (due to sexist and intersectional suppression), squatters (protesting against gentrification), workers (loosing their jobs), the Roma etc. Are they predestined actors of utopian imagination and concrete utopias? Can one even go that far to say, that utopian action is closely linked to misery ... (especially obvious in the text on the Roma)? Is a utopian momentum linked to the experience of a dystopian present?

OR: There are groups of people today (and I wouldn't exclude myself from them) who by no means can afford giving up the idea of utopia and the strife for a better world. As Occupy Wall Street pointed out with their assumption of the $1 \%$ versus the $99 \%$ it is for sure a very large part of the society that should have something to win in case of a radical democratic transformation which includes redistribution of property and wealth and the cancellation of debts. So the groups you mention, and there are definitely more in society such as all kinds of immaterial workers, to which Antonio Negi and Michael Hardt referred to as multitude, will very likely become central protagonists in coming struggles.

MSG: Solidarity among marginalised groups is a controversial subject. Balibar for example described nationalist tendencies of the French Communist Party, "protecting" the national workers from the immigrant workers, and also in the text on the Roma in Utopian Pulse - Flares in the Darkroom it is described how scarce resources create discords and fights within marginalised groups. How do you imagine to further alliances among different marginalised groups?

OR: I think specific moments of political ruptures, rare windows of opportunities, need to be used by social movements in order to create a shift in society that changes and improves the living conditions for the large part of society, and that lead to a democratic transition. In such a situation existing tensions between marginalised groups can be reduced, through the redistribution of resources from the top to the poor. Such a 
moment of political rupture could for example be observed at the beginning of the Bolivarian Process when Hugo Chávez became president in Venezuela in 1998, and very soon huge programs - "missions" - were initiated that improved health care, housing, education and nurture for all groups that were marginalised in the previous decades. And meeting basic needs enabled millions of people to participate actively in democratic decision-making processes, making possible the Bolivarian Process.

MSG: What is the relation of the concrete utopian projects to the art world? In one of the texts I was reading, "people who would usually not enter such an institution" entered the salons? What a dimension can an art institution offer to the utopian action?

OR: What we observed in the more than 40 events that took place within the seven salons is that, in most of these salons, more people who are not connected to the art field attended than cultural producers. It was interesting to observe how much the audience changed from salon to salon, also in terms of numbers. As all of the salons had a quite clear concept and theme, and most of the audience came directly from the addressed fields, such as people interested in urban politics or struggles against gentrification for Salon Public Happiness by Christoph Schäfer, or Viennese Afghan exiles for Mariam Ghani's Salon of the Whirlwind that dealt with Afghanistan's short communist period through unfinished films from that time.

What art can offer in my opinion are spaces, which can be used for thinking and imagination, a friendly environment where time can be spent together, where activities can be shared with other groups, where exchange can take place. I think there is a lack of such spaces in today's society. And even if I as an artist feel the necessity to go beyond the limitations of art institutions and to become more active outside of them again, I have at the same time the feeling that these art institutions need to be strengthened, that we need to keep working inside them, that we need to defend them against cutbacks in times of austerity or against political interventions, and that we need to fight to transform these institutions into open platforms from where to speak.

MSG: Most of the groups and examples mentioned are very local initiatives (anchored in their neighbourhoods, communities), is this accidental or closely connected to the possibilities of concrete utopia?

OR: Even though most examples are rooted locally, they are usually in exchange with comparable activities elsewhere. For example, the worker-controlled factory RiMaflow in Milan I focussed on in my artistic work together with Dario Azzellini, which is documented in the publication, is in frequent exchange with other worker-controlled factories in Europe and in Latin America. The inspiring experiments and activities of the Isola Art Center would be impossible without numerous collaborators and visitors from elsewhere who take the experiences they make in Italy back to their home cities. Even though the Gezi Park and Taksim Square protests, that Salon Public Happiness and Halil Altindere with his banner focus on, took place in one large city, these protests were directly connected to protests in other cities, such as the Occupy movement or the "Arab Spring". So I actually see all activities loosely connected with each other and as part of a larger attempt of organising to try out alternatives.

MSG: The second part of the utopian dialectics, the assertion of what is not, remains ungraspable throughout the book, but again and again seems to pop up like a common ground that does not need to be discussed, referring to equality, ecology, 
self-administration. Would you dare to describe an assertion of what is not such, as Charles Fourier did it in the nineteenth century (the sea made of lemonade etc.)?

OR: The exhibition, and to a smaller extent the book, assemble the attempts of 160 artists, curators and theorists of Utopian Pulse - Flares in the Darkroom to present or define what they think is important in relation to utopian thinking. This could have been even broader and cover further fields in case of a larger involvement of people. So "what is not" is perhaps that all these attempts, and many more, become active and meaningful at a specific place and at the same time, so that current power-relations are not only critically discussed and challenged, but made history.

\section{NOTES}

1. Doujak I. \& Ressler O. (eds). 2015. Utopian Pulse - Flares in the Darkroom, Pluto Press, 288 p., 2015, funded by the Austrian Science Fund (FWF)

\section{AUTHORS}

\section{OLIVER RESSLER}

Oliver Ressler, born 1970, lives and works in Vienna and produces installations, projects in public space, and films on issues such as economics, democracy, global warming, forms of resistance and social alternatives. He has had solo exhibitions in major art spaces such as Berkeley Art Museum, USA; Platform Garanti Contemporary Art Center, Istanbul; Museum of Contemporary Art, Belgrade; Centro Cultural Conde Duque, Madrid; Alexandria Contemporary Arts Forum, Egypt; The Cube Project Space, Taipei; Wyspa Institute of Art, Gdansk, Lentos Kunstmuseum, Linz; and currently at Centro Andaluz de Arte Contemporaneo - CAAC, Seville. Ressler has participated in more than 250 group exhibitions, including Museo Reina Sofía, Madrid; SALT Beyoğlu, Istanbul; Yerba Buena Center for the Arts, San Francisco; Van Abbe Museum, Eindhoven; MASSMoCA, North Adams, USA and at the biennials in Prague (2005), Seville (2006), Moscow (2007), Taipei (2008), Lyon (2009), Gyumri (2012), Venice (2013), Athens (2013, 2015), Helsinki (2014), and Quebec (2014). A retrospective of his films took place at Centre d'Art Contemporain Genève in 2013. For the Taipei Biennale 2008, Ressler curated A World Where Many Worlds Fit. A traveling show on the financial crisis, It's the Political Economy, Stupid, co-curated with Gregory Sholette, has been presented at eight venues since 2011. In collaboration with Ines Doujak he cocurated Utopian Pulse - Flares in the Darkroom at Secession in Vienna in 2014. 


\section{MEIKE SCHMIDT-GLEIM}

Meike Schmidt-Gleim is a philosopher and artist, and lives in Vienna and Paris. She has directed various research projects such as The History of Europe seen through the lens of the barbarian (20072010) and has exhibited as an artist in the Vienna Secession, the Salzburger Kunstverein or the Palais de Tokyo in Paris. Her publications include: The Meanings of Europe (editor), Routledge, London 2013; "Europe as imaginary object", in: Parliament and Europe, Nomos Verlag, BadenBaden 2011; Die Regierung der Demokratie (monography), Passagen Verlag, Vienna 2009; as well as numerous publications on the ATLAS OF ARCADIA:

www.anthropologicalmaterialism.hypotheses.org 